ENCYCLOPEDIA OF TIDEPOOLS AND ROCKY SHORES 


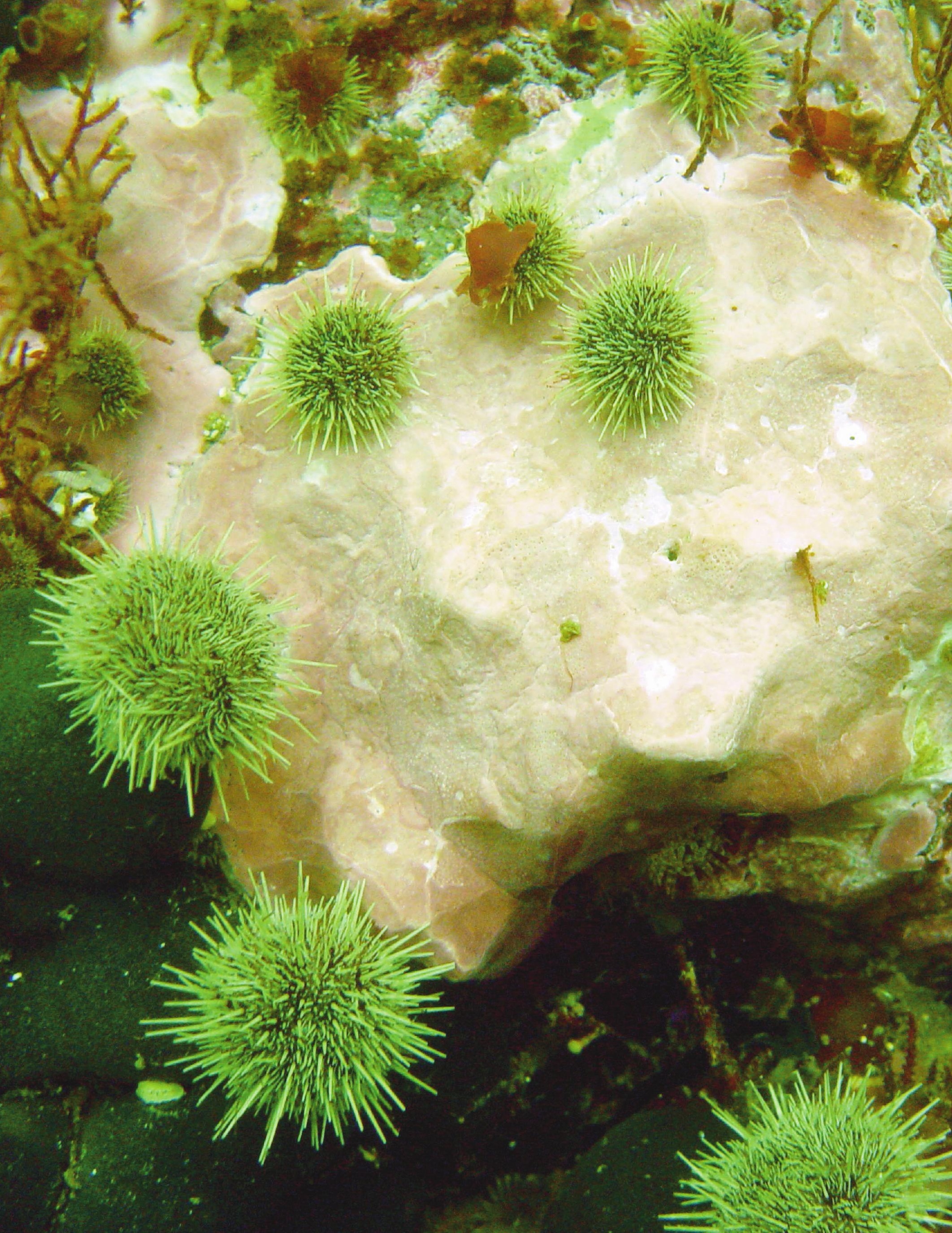




\section{ENCYCLOPEDIA OF TIDEPOOLS AND ROCKY SHORES}

EDITED BY

MARK W. DENNY

Stanford University

\section{STEVEN D. GAINES}

University of California, Santa Barbara

甲

UNIVERSITY OF CALIFORNIA PRESS

Berkeley Los Angeles London 
University of California Press, one of the most distinguished university presses in the United States, enriches lives around the world by advancing scholarship in the humanities, social sciences, and natural sciences. Its activities are supported by the UC Press Foundation and by philanthropic contributions from individuals and institutions. For more information, visit www.ucpress.edu.

Encyclopedias of the Natural World, No. I

University of California Press

Berkeley and Los Angeles, California

University of California Press, Ltd.

London, England

(C) 2007 by the Regents of the University of California

Library of Congress Cataloging-in-Publication Data

Encyclopedia of tidepools and rocky shores / Mark W. Denny and Steven D. Gaines, editors.

p. $\mathrm{cm}$.

Includes bibliographical references.

ISBN 978-0-520-25118-2 (cloth: alk. paper)

I. Tide pool ecology—Encyclopedias. 2. Tide pools—Encyclopedias.

3. Seashore ecology_Encyclopedias. 4. Seashore-Encyclopedias. I. Denny,

Mark W., I95I- II. Gaines, Steven D. (Steven Dean), 1955-

QH541.5.S35 5532007

577.69 '9--dc22

2006035368

Manufactured in Singapore

$\begin{array}{llll}\text { IO } & 09 & 08 & 07\end{array}$

IO $\quad 9 \begin{array}{lllllllll} & 8 & 7 & 6 & 5 & 4 & 3 & 2 & \text { I }\end{array}$

The paper used in this publication meets the minimum requirements of ANSI/NISO Z39.48-I992 (R I997) (Permanence of Paper).

Cover photographs: At bottom: J. Rotman (C) CORBIS. In top row, from left: tidepools at Point Piños, Pacific Grove, California, photograph by Adam Schneider, http://adamschneider.net; mussel extending byssal threads, photograph courtesy of Laura Coutts; Point Piños, photograph by Adam Schneider; red and purple urchins, photograph courtesy Richard B. Emlet. 